turn to biology and to apply in it the knowledge and methods of the physical sciences that success for the scheme and progress in biology will lie. This needs to be emphasized; experionce has shown that graduates and even their sponsoring professors havo sometimes failed to understand the purpose of these awards. For example, it is not uncommonly proposed that a graduate in organic chemistry should use his award to take a course in biochemistry and, at the same time, embark on some biochemical research. This would fall far short of the purpose of these awards. Recipients of awards have made thoir subsequent carcers in teaching and in research in biological and medical departments of universities and in resoarch institutes for biological subjects; two recipients found their way back into physical subjects. Subjects of recipients' first degree (total for scholars, first figure; for bursars, second figure) were: physics $(5,6)$; chemistry $(4,4)$; mathematics $(2,2)$; general sciences $(1,-)$. Subjects studied under award were: physiology $(7,7)$; zoology $(4,2)$; botany and zoology, $(2,2)$; biophysics $(-, 1)$. It is noteworthy that only once since 1952 was botany chosen for postgraduate study. Further information and application forms can be obtained from the Director, the Nuffield Foundation, Nuffield Lodge, Regent's Park, London, N.W.1.

\section{Training Course in Taxidermy}

THE Museums Association, through the generosity of the Carnegie United Kingdom Trust and in association with several of the major museums, is offering opportunities for, and financial assistance in, training in taxidermy to a limited number of individuals who intend to follow a career in the museum field. The training course will cover a period of three years and candidates should be between the ages of 18 and 25 years and have a sound general education. Forms of application and further information can be obtained from the Secretary, the Museums Association, 87 Charlotte Street, London, W.1. Completed applications should be submitted not later than February 15.

\section{University News:}

Hull

Prof. R. H. Barback has been appointed to the newly established second chair of economics in the Department of Economics and Commerce. The following appointments have also been announced: Senior Lectureships, Dr. J. Annett (psychology); G. Richardson (education); Research Fellowship, Dr. D. D. Singh (chemistry).

London

Tye following titles have been conferrod: professor of botany on Dr. Maud B. E. Godward, in respect of her post at Queen Mary College; professor of zoology on Mr. H. R. Hewer, in respect of his post at the Imperial College of Science and Technology; professor of oral anatomy on Dr. H. J. J. Blackwood, in respect of his post at the Royal Dental Hospital. Dr. D. A. Mitchison has been appointed reader in bacteriology at the Postgraduate Medical School and Dr. D. A. Walkor has been appointed reader in enzymology at the Imperial College of Science and Technology.

Manchester

THE following appointments have been made: Readerships, Dr. G. Allen (chemistry); Dr. C. N. W. Litting and Dr. G. R. Hoffmann (electrical engineering); D. R. Bland and Dr. S. Levine (mathematics); Dr. S. D. Silvey (statistics in the Department of Mathematics); Dr. G. M. Leak (metallurgy); Dr. A. Herzonberg (theoretical physies); Dr. E. L. Patterson (anatomy); Dr. A. H. Gowonlock (chemical pathology). Senior Lectureships, Dr. H. O. Pritchard (chemistry); Dr. F. H. Sumner (computer seience); Dr. E. R. Bryan and F. Cheers (engineering); Dr. J. H. Gerrard (mechanics of fluids); Dr. D. St. P. Bunbury (physics); Dr. K. G. Cowling (agricultural economics); Dr. D. Bulmer (anatomy); Dr. F. B. Beswick (experimental physiology); Dr. S. 'Thomas (physiology). Lectureships, Dr. C. A. Stace (botany); Dr. R. Bryant (chemistry); C. T. Elliott and J. M. Townsend (electrical engineering); P. J. Vermeulen, J. M. Davies, R. C. F. Dye, P. Mason, T. A. Henry, R. J. Aird and W. B. Wilkinson (engineering); Dr. J. E. Pollard (geology); G. Walker, Dr. W. A. Sutherland and Dr. C. E. M. Yates (mathematics); Dr. S. Blairs (metallurgy); G. G. Benson and N. A. Dickinson (pharmacy); Dr. J. W. Murphy and Dr. J. S. Dowker (theoretical physies); E. J. Daintree and Dr. R. J. Long (radioastronomy); Dr. M. P. Hatton (chemical bacteriology).

Newcastle upon Tyne

Dr. J. H. D. Prescott has been appointed lecturer in animal production in the School of A.griculture as from December 1, 1964.

Reading

The title of research professor has been conferred on Dr. S. K. Kon, deputy director of the National Institute for Research in Dairying and head of its Department of Nutrition, and on Dr. S. J. Folley, head of the Department of Physiology in the Institute.

\section{Announcements}

Prof. A. Holmes has been awarded the MakdougallBrisbane Prize for the period 1962-64, by the Council of the Royal Society of Edinburgh, in recognition of his contributions to the fundamental philosophy of the Earth sciences.

Brigadier R. C. A. EDGE has been appointed directorgeneral of the Ordnance Survey, with the rank of majorgeneral. Brigadier Edge will succeed Major-General A. H. Dowson, who is retiring in September.

DR. H. R. V. A.RNSTEIN has been appointed committee secretary, and Prof. K. S. Dodgson meetings secretary, of the Biochemical Society, following the recent retirement of Dr. P. N. Campbell.

ON February 1, the Manchester Office of the Cement and Concrete Association moved into new premises at the following address: Cement and Concrete Association, Television House, 10 Mount Street, Manchester, 2.

VARIAN Associates, LTD, have moved to a new address at Russell House, Molesey Road, Walton-onThames, Surrey.

AN ordinary mooting of tho Scottish Section of the Society for Analytical Chemistry will be held in the University of Strathelyde on February 26. Dr. D. T. Lewis will present a paper entitled "Research Work at the Government Laboratory". Further information can be obtained from the Society for Analytical Chemistry, 14 Belgrave Square, London, S.W.1.

As exhibition of the Dead Sea Serolls, arranged by the Smithsonian Institution and sponsored by the Government of Jordan, will be held in the Institution during February 28-March 21. The exhibition will also visit Philadelphia (April 3-25), Berkeley (May 8-30), Los Angeles (June 12-July 5), Omaha (July 17-August 8), and Baltimore (August 21-September 19).

A Jornt meeting of the North of England Section of the Society for Analytical Chemistry and the Newcastle upon Tyne and North East Coast Section of the Royal Institute of Chemistry will be held in Nowcastle upon Tyne on February 16. Mr. G. B. Crump will present a paper entitled "Thin-layer Chromatography". Further information can be obtained from the Society for Analytical Chemistry, 14 Belgrave Square, London, S.W.1. 